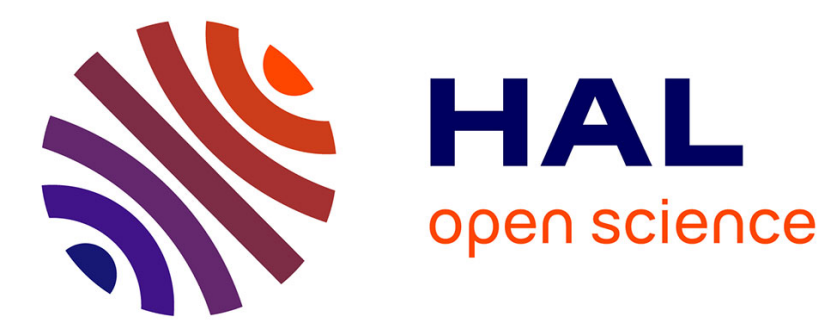

\title{
Small GTPases of the Rho family and cell transformation.
}

\author{
Philippe Fort
}

\section{To cite this version:}

Philippe Fort. Small GTPases of the Rho family and cell transformation.. Progress in molecular and subcellular biology, 1999, 22, pp.159-81. hal-00875311

\section{HAL Id: hal-00875311 \\ https://hal.science/hal-00875311}

Submitted on 21 Oct 2013

HAL is a multi-disciplinary open access archive for the deposit and dissemination of scientific research documents, whether they are published or not. The documents may come from teaching and research institutions in France or abroad, or from public or private research centers.
L'archive ouverte pluridisciplinaire HAL, est destinée au dépôt et à la diffusion de documents scientifiques de niveau recherche, publiés ou non, émanant des établissements d'enseignement et de recherche français ou étrangers, des laboratoires publics ou privés. 
Small GTPases of the Rho family and cell transformation

Philippe Fort

Institut de Génétique Moléculaire de Montpellier UMR CNRS 5535

1919, route de Mende

F-34293 Montpellier cedex 05 France

Tel: (33) 67613644

Fax: (33) 67040231

E-mail: fort@igm.cnrs-mop.fr 


\section{TABLE OF CONTENTS}

SMALL GTPASES OF THE RHO FAMILY AND CELL TRANSFORMATION ............................. 1

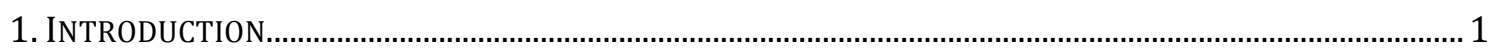

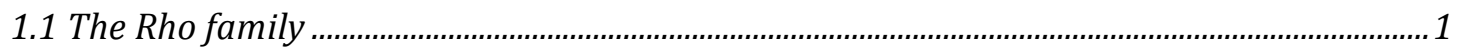

1.2 Regulators of the Rho family and their oncogenic properties ................................................2

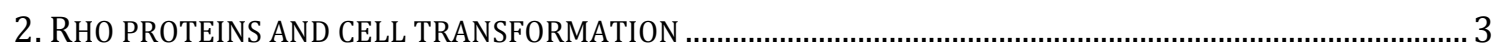

2.1 Intrinsic transforming properties of Rho proteins ......................................................................

2.2 Crosstalk between Rho controlled pathways .........................................................................

3. CROSSTALK BETWEEN RAS AND RHO-DEPENDENT PATHWAYS IN CELL TRANSFORMATION..................... 6

3.1 Cooperation between Ras and Rho pathways ........................................................................ 6

3.2 Cooperation between Raf and Rho pathways..........................................................................

4. SigNALLING PATHWAYS DOWNSTREAM OF RHO PROTEINS INVOLVED IN CELL TRANSFORMATION..... 10

4.1 Rho-dependent activation of the JNK/SAPK pathway ........................................................... 10

4.2 The cytoskeleton and Rho proteins ..................................................................................... 12

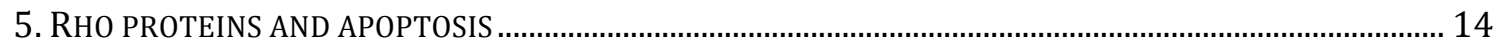

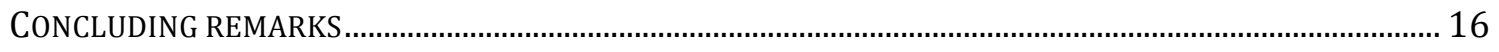

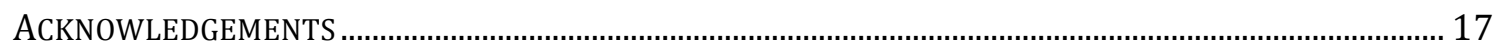

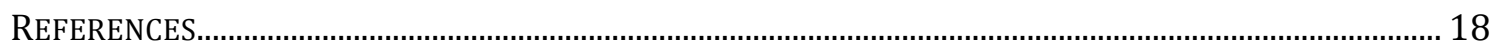




\section{Small GTPases of the Rho family and cell transformation}

\section{Introduction}

The Rho GTPases form a distinct subgroup of the Ras superfamily of low molecular weight GTP binding proteins. These proteins are implicated in signal transduction leading to changes in membrane structures and cytoskeletal reorganisation associated with changes in cell shape. Like other Ras-related proteins, Rho GTPases are thought to adopt either an active GTP-bound conformational state or an inactive GDPbound state. Although cycling between these states is controlled by several regulatory proteins, mutations in Rho proteins can favour a specific status : an asparagine substitution in Rho at position homologous to Ras threonine 17 led to a drop in the affinity for GTP. This mutated protein acts as an inhibitor by sequestering positive regulatory factors thereby preventing activation of the endogenous Rho GTPase. Conversely, substitutions of residues similar to those found in oncogenic Ras proteins (e.g. G12V or Q61L) led to constitutively active Rho proteins, due to a reduced GTP hydrolysis. Once loaded with GTP, the GTPase gains the ability to bind cognate effector downstream targets, which converts the input signal into a specific set of activations.

Over the past few years, it has been shown that Rho GTPases play a role in the organisation of the actin cytoskeleton, and also have critical functions in the control of cell proliferation. In the present review, I address the implication of the Rho family in cell transformation and apoptosis, as well as in the regulatory crosstalk between pathways controlled by Rho and Ras proteins.

\subsection{The Rho family}

Rho proteins are key elements in the regulation of numerous functions such as the assembly of the cytoskeleton ${ }^{1}$, cell motility ${ }^{2}$, smooth muscle contraction ${ }^{3}$, metastasis ${ }^{4}$, apoptosis ${ }^{5}$, as well as various aspects of cell polarity. The Rho family is made of two branches, one comprising $\operatorname{RhoA}^{6}, \operatorname{RhoB}_{\text {and }} \operatorname{RhoC}^{7}, \operatorname{RhoD}^{8}, \operatorname{RhoE}^{9}$ and $\operatorname{RhoL}^{10}$, the 
other comprising Rac1 and Rac2 ${ }^{11}, \operatorname{Rac}^{12,13}{ }^{13} \operatorname{RhoG}^{14}, \mathrm{Cdc} 42 \mathrm{Hs}{ }^{15}, \mathrm{TC}_{10}{ }^{16}$ and TTF ${ }^{17}$. RhoA, RhoB and RhoC control the formation of focal adhesions and actin stress fibres in fibroblasts ${ }^{18-20}$, while RhoD causes rearrangements of the actin cytoskeleton and controls early endosome motility and distribution ${ }^{8}$. Rac proteins are required for growth factorinduced membrane ruffling and lamellipodia formation in fibroblasts ${ }^{1,18}$. Additionally, in neurons, their activity is required for axonal outgrowth ${ }^{21}$ while in phagocytic cells, they play a role in the activation of NADPH oxidase ${ }^{22-25}$. Cdc42 is involved in the establishment of cell polarity in yeast ${ }^{26,27}$ and the mammalian homologue Cdc42Hs is required in the polarization of helper T cells toward antigen-presenting cells ${ }^{28}$. Cdc $42 \mathrm{Hs}$ also regulates the formation of filopodia in growth stimulated fibroblastic cells ${ }^{29}$. In addition to their role in cell morphology, Rho, Rac and Cdc42Hs have been shown to promote cell cycle progression through $\mathrm{G}_{1}$, trigger DNA synthesis ${ }^{30}$ and regulate the activation of the ubiquitous transcription factor SRF (serum response factor) ${ }^{31}$. However, the effect induced by $\mathrm{Cdc} 42 \mathrm{Hs}$ is still controversial, as other reports indicate that its expression causes cytokinesis arrest ${ }^{32}$, and inhibits serum-stimulated cell cycle progression at $\mathrm{G} 1 / \mathrm{S}$ through a mechanism requiring the MAP kinase $\mathrm{p} 38 / \mathrm{RK}^{33}$. Rac, Cdc42Hs and RhoG also stimulate the c-Jun kinase JNK/SAPK, an enzyme essential in the signalling pathways from IL-1 or TNF $\alpha$ receptors ${ }^{34,35}$.

\subsection{Regulators of the Rho family and their oncogenic properties}

The transition between GTP-bound and GDP-bound conformational states of the Rho GTPases is controlled by a wide array of regulatory proteins : guanine nucleotide exchange factors (GEFs), GTPase-activating proteins (GAPs) and GDP-dissociation inhibitory factors (GDIs). So far, only three GDIs proteins have been characterized, namely RhoGDI, D4/LyGDI and $\gamma$-GDI/RhoGDI3. RhoGDI is ubiquitously expressed in mammalian tissues and organs ${ }^{36}$, while D4/LyGDI expression is restricted to

hematopoietic tissues ${ }^{37,38} \cdot \gamma$-GDI/RhoGDI3 is preferentially expressed in the brain and pancreas ${ }^{39}$, and has a binding specificity for RhoB and RhoG ${ }^{40}$. 
A high number of GAPs acting on the Rho family have been isolated. They include $\mathrm{p} 190^{41}, \mathrm{p} 190-\mathrm{B}^{42}$, RhoGAP $^{43}, \mathrm{abr}^{44}, \mathrm{bcr}^{45}, \mathrm{Cdc} 42 \mathrm{Hs}-\mathrm{GAP}^{46,47}, 3 \mathrm{BP}-1^{48}, \mathrm{p}^{4} 5^{49}$, n-chimaerin ${ }^{50}, \mathrm{p} 115^{51}, \mathrm{RIP} 1 / \mathrm{RLIP} 76{ }^{52,53}$, myr-5 ${ }^{54}$, the myosin IXb ${ }^{55}$, graf ${ }^{56}$, and IQGAP1 ${ }^{57}$. These proteins exhibit a wide range of tissue specificity and act differentially on the members of the Rho family ${ }^{58,59}$.

The first characterized exchange factor was $\mathrm{Dbl}$, an oncoprotein isolated from diffuse $B$ cell lymphomas ${ }^{60-62}$. Dbl was shown to share a conserved 250 amino acids domain (DH domain) with $\mathrm{Cdc} 24$, an exchange factor for yeast $\mathrm{Cdc} 42^{63}$. Since the initial characterization of $\mathrm{Dbl}$ and $\mathrm{Cdc} 24$, additional members of the $\mathrm{Dbl}$ family have been characterized, including oncoproteins such as bcr ${ }^{45}$, vav ${ }^{64}$, ost ${ }^{65}$, tiam-1 ${ }^{4}$, ect2 ${ }^{66}$, tim ${ }^{67}$, fgd $1{ }^{68}, \mathrm{abr}^{44}, \mathrm{dbs}{ }^{69}, \mathrm{lbc}{ }^{70}$, Ifc ${ }^{71}$ and Isc ${ }^{72}$. Like GAPs, GEFs factors exhibit a wide diversity in their tissue distribution and specificity towards Rho members.

Thus, only proteins capable of activating one or several Rho proteins have oncogenic properties ${ }^{73}$. A direct link between activation of Rho GTPases and cell transformation has been demonstrated by the finding that the GEF activity of the $\mathrm{dbl}$ exchange factor is required for cell transformation ${ }^{62}$. Since that GEFs may activate one or several Rho GTPases, this resulted to the hypothesis that one or several pathways controlled by Rho proteins are involved in cell transformation.

\section{Rho proteins and cell transformation}

\subsection{Intrinsic transforming properties of Rho proteins}

During the last ten years, several studies have investigated the transforming potential of the Rho family members. It was first observed that although expression of activated RhoA (V14-RhoA) in NIH3T3 cells did not cause focus formation in monolayers or growth in soft agar, it led to a reduced dependence on serum for growth, a higher saturation density and a tumourigenic potential in nude mice ${ }^{74}$. Since then, many Rho proteins have been examined for their focus forming activity in NIH3T3 cells. Interestingly, like V14-RhoA, wild-type RhoA was also shown to confer a reduced anchorage- and 
serum-dependent growth ${ }^{75}$. V14-RhoA and wild-type RhoA transfected cells were able to induce tumours in nude mice, albeit at a much lower efficiency for the wild-type RhoA. RhoA-induced tumours consist in well-differentiated fibrosarcomas, which exhibit intersecting bundles of spindle cells. Similar tumour types were obtained in nude mice transplanted with V14-RhoB expressing cells ${ }^{76}$.

Analysis of Rac1 ${ }^{77}$ and RhoG ${ }^{35}$ showed that expression of either protein in NIH3T3 cells led to a partial loss of cell contact inhibition and a reduced dependence on serum. In addition, overexpression of constitutively active Rac1 (V12-Rac1) induced invasiveness of BW5147 T-lymphoma cells in a culture assay system, as did the Racspecific exchange factor Tiam $1^{78,79}$. The morphology of V12-Rac1-expressing NIH3T3 cells was found to be polymorphic, appearing either as large flat cells with extensive membrane ruffling, similar to dbl-transformed cells ${ }^{60}$, or spindle shaped and refractile, as observed for V14-RhoA-transformed cells. These cells were also characterized by a high proportion of multinucleated cells ${ }^{80}$. Subsequent transplantation in nude mice induced tumours at the same efficiency as RhoA ${ }^{77,81}$.

Although expression of activated $\mathrm{Cdc} 42 \mathrm{Hs}$ protein $(\mathrm{V} 12-\mathrm{Cdc} 42 \mathrm{Hs})$ in Rat1 or NIH3T3 cells led to a dramatic loss of anchorage dependence, it had no effect on serumdependent growth and on contact inhibition ${ }^{35,80}$. Interestingly, V12-Cdc42Hs-expressing Rat1 cells readily produced tumours in nude mice ${ }^{80}$ but did not form foci ${ }^{35}$. These cells showed a high membrane activity, which were generally multinucleated with a rounded phenotype and a reduced adhesion to the substratum ${ }^{80}$.

It thus appears that members of the Rho family have similar transforming potentials : decreased anchorage-dependent cell growth (Cdc42Hs and RhoA), reduction of cell contact inhibition and serum dependence (Rac1 and RhoG), and tumour formation in nude mice ( $\mathrm{Cdc} 42 \mathrm{Hs}$, Rac1 and RhoA). These results led to the question of whether these proteins activate distinct pathways leading to similar phenotypic changes or whether their shared properties are mediated by a single pathway. Such a situation was 
described for the control of actin cytoskeleton, where activated Cdc42Hs activates Rac1, which in turn can modulate the activity of Rho ${ }^{18,29,82}$.

\subsection{Crosstalk between Rho controlled pathways}

In contrast with the low focus forming activity of cells transfected with GTPases, cells expressing exchange factors display a high focus forming activity. As exchange factors can activate several distinct GTPases, this suggests a probable cooperation between Rho-controlled pathways. For instance, the Ost exchange factor potentially acts on RhoA and Cdc42Hs, and also has the ability to bind the GTP-bound form of Rac1 ${ }^{65}$. Thus, the activated Ost protein might express its full oncogenic properties through the activation of three distinct Rho-dependent pathways.

Analysis of coordinated crosstalk has been worked out by coexpressing various combinations of constitutively active and dominant negative Rho protein variants. Whereas constitutively active individual Rho GTPases showed very weak focus forming activities, their simultaneous expression results in much higher focus formation ${ }^{35}$ : Coexpression of V12-Cdc42Hs and V12-Rac1, or V12-Cdc42Hs and V12-RhoG produced a high focus forming activity, in the range of that observed for Ost ${ }^{65}$. Coexpression of V12-RhoG and V12-Rac1 elicited a focus forming activity an order of magnitude lower ${ }^{35}$. Interestingly, coexpression of N17-Rac1, a dominant negative Rac, caused an $80 \%$ inhibition in the focus forming activity of cells expressing V12-Cdc42Hs and V12-RhoG, while expression of $\mathrm{N} 17-\mathrm{RhoG}$ and $\mathrm{N} 17-\mathrm{Cdc} 42 \mathrm{Hs}$ only marginally reduced the focus formation elicited by V12-Rac1/V12-Cdc42Hs and V12-Rac1/V12-RhoG, respectively. This suggests that Rac acts downstream of RhoG in a pathway independent from Cdc42Hs. Along the same line, coexpression of $\mathrm{V} 12-\mathrm{Cdc} 42 \mathrm{Hs}$ and $\mathrm{N} 17-\mathrm{Rac} 1$ strongly inhibited the generation of multinucleated cells as well as PDGF-induced lamellipodia ${ }^{80}$. In contrast, anchorage-independent growth in soft agar was not significantly inhibited. This suggests that $\mathrm{Cdc} 42 \mathrm{Hs}$ might control at least two distinct pathways: one pathway responsible for lamellipodia and cleavage furrow formation where $\mathrm{Cdc} 42 \mathrm{Hs}$ is upstream of 
Rac, and a second Rac-independent pathway, which controls anchorage-independent cell growth.

Thus, although $\mathrm{Cdc} 42 \mathrm{Hs}$ was shown to act upstream of Rac1 in pathways signalling cytoskeletal reorganization of various cell types ${ }^{29,82-84}$, we can conclude that Rac1 and $\mathrm{Cdc} 42 \mathrm{Hs}$ delineate at least two independent pathways that cooperate in cell transformation (Figure 1). Cdc42Hs controls the anchorage-dependent cell growth, while Rac1 controls cell contact inhibition. RhoG appears to be involved in some of the same pathways as Rac1, probably acting upstream of Rac. However, RhoG is also involved in different pathways, as it cooperates independently with Rac1 and $\mathrm{Cdc} 42 \mathrm{Hs}$ in focus formation.

The observation that Rho-dependent pathways leading to cell transformation follow a scheme that does not superimpose with the regulatory cascade described for the control of actin cytoskeleton (see page 7). This suggests that the expression of V12Cdc42Hs only partially activates the endogenous Rac1 protein, e.g. by acting only on Rac1 localised in specific sub-cellular domains or by increasing at a lower extent the amount of GTP-bound Rac1.

\section{Crosstalk between Ras and Rho-dependent pathways in cell transformation}

\subsection{Cooperation between Ras and Rho pathways}

Several lines of evidence led to the hypothesis that Rho proteins are activated in Ras-controlled pathways leading to cell transformation. i) Microinjection of constitutively active or wild-type Ras proteins has long been known to elicit extensive membrane ruffles and phase-fluid pinocytosis in resting cells ${ }^{85}$. This feature has been shown to require an active endogenous Rac1 protein ${ }^{18}$. ii) In cells stimulated by growth factors, the Rho-GAP p190 protein 41 is rapidly tyrosine-phosphorylated and clusters with the Ras-GAPp120/p62Dok complex ${ }^{86}$. iii) More recently, a direct functional connection between Ras signalling and Rho protein activity was reported in the yeast S. pombe, in 
which signals that control normal morphology and mating are conveyed from Ras 1 to Cdc42Sp ${ }^{87}$.

The direct implication of Rho-dependent pathways in Ras mediated transformation was further investigated by coexpressing oncogenic Ras proteins with dominant inhibitory and activated versions of Rho proteins. Ras-induced focus formation was found to be inhibited upon expression of all tested dominant negative mutants of Rho family members, i.e. Rac1, RhoA, RhoB, Cdc42 and RhoG 35, 76, 77, 80, 81, 88. More accurate analyses revealed differences in the effects of these inhibitory protein on Ras-induced transformatiob ${ }^{80}$. N17-Cdc42 was shown to revert the transformed morphology of Rasexpressing cells whereas N17-Rac1 did not. Conversely, expression of N17-Rac1 strongly inhibited low-serum growth of Ras-transformed cells, whereas N17-Cdc42Hs had a limited effect. Both proteins strongly inhibited cell growth in soft agar.

The overall inhibitory effect of N17 variants was not due to a toxic effect, as their expression at similar levels induced minimal changes in NIH3T3 cells: N17-Rac1 and N17-RhoG expression led to a reduction in cell saturation density but did not modify cell growth in $10 \%$ foetal calf serum ${ }^{35,77}$, while no changes in morphology or cell growth were reported in $\mathrm{N} 17-\mathrm{Cdc} 42 \mathrm{Hs}$-expressing cells ${ }^{35,80}$. Expression of N19-RhoA did not reduce cell cloning efficiency, although it led to a reduction in stress fibre formation ${ }^{81}$. In addition to inhibitory mutants, overexpression of p190-RhoGAP [which has marked preferential activity for Rho(A,B,C) in vitro [Ridley, 1993 \#108]] was recently shown to suppress HaRas mediated cell transformation ${ }^{89}$. This demonstrates that the amount of intracellular GTP-bound Rho is critical for Ras transformation. Thus, although the possibility remains that some mutants inhibit non specifically distinct Rho proteins, these data suggest that multiple pathways controlled by Rho proteins are necessary for full Ras-dependent transformation.

The implication of Rho-dependent pathways in cell transformation was further strengthened by the phenotypic changes observed in cells coexpressing activated Ras 
and Rho proteins. L63-RhoA or 1115-Rac1 expression led to a twofold increase in the number of L61-Ras-induced foci ${ }^{88}$. Similarly, a 3-fold to 4-fold increase in activated Ras focus forming activity was observed upon coexpression with V12-Rac1, and to a lower extent, with $\mathrm{V} 12-\mathrm{RhoG}$ and $\mathrm{V} 12-\mathrm{Cdc} 42 \mathrm{Hs}{ }^{35}$. In addition, the morphology of the resulting foci was dramatically altered. Whereas cells expressing L61-Ras were highly refractile and spindle-shaped, coexpression with L63-RhoA or 1115-Rac1 produced foci with rounded refractile and poorly adherent cells.

Thus, these data are consistent with the hypothesis that distinct Rho-dependent pathways are important in Ras-mediated transformation. Even though Rho GTPases do not induce focus formation on their own, they synergize with Ras, suggesting that Rho proteins modulate the susceptibility of NIH3T3 cells to Ras-mediated transformation (Figure 2).

\subsection{Cooperation between Raf and Rho pathways}

Ras-dependent signal transduction has been extensively studied over the past ten years. Upon activation by ligand-stimulated tyrosine kinase receptors, activated Ras complexes with several effector proteins ${ }^{90}$, including Raf-1, phosphatidyl-inositol-3-OH kinase $(\mathrm{PI} 3 \mathrm{~K})$ and MEK kinase 1. Once phosphorylated at the plasma membrane, the activated Raf-1 kinase phosphorylates the MAPK kinases MEK1 and MEK2, which in turn activate p42 and p44 MAPK (extracellular signal-regulated kinases, ERKs) ${ }^{91}$. Phosphorylated ERKs then translocate into the nucleus, where they activate nuclear transcription factors, eventually leading to gene activation and mitogenesis. As Rho proteins involved in Ras-mediated transformation might affect several pathways downstream of Ras, it was crucial to determine the relationships between Rho-dependent pathways and the Raf-1/ERK pathway. Such an analysis was worked out by coexpressing dominant negative or constitutively active versions of Rho(A, B), RhoG, Rac1 and Cdc42Hs proteins with activated forms of Raf-1. Coexpression of the dominant negative N19-RhoB in Rat1 fibroblasts did not reduce foci formation elicited by the v-Raf oncogene 
${ }^{76}$. In NIH3T3 cells, the focus forming activity of Raf-CAAX, which constitutively activates the MAP-kinase pathway ${ }^{92}$, was not reduced upon expression of N17-Rac1 ${ }^{77,80}$. Identical results were obtained upon coexpression of N17-Rac1, N17-RhoG and N17-Cdc42Hs proteins with the v-Raf oncogene ${ }^{35}$. These results therefore suggest that Rho-dependent pathways involved in Ras transformation are distinct from the Raf-1/ERK pathway. This was further confirmed by assaying for cooperation of both types of pathways in transformation. Expression of each activated Rho GTPase led to a 2-5 fold increase in vRaf or Raf-CAAX focus forming activity ${ }^{35,76,77,80,81,88}$. However, conflictual results were obtained with RhoA and Cdc42Hs, where dominant negative proteins inhibited Raf-CAAXinduced focus formation ${ }^{80,81}$. Although not investigated, a reason for this discrepancy might lie in different behaviour between v-Raf and Raf-CAAX.

The distinct nature of Rho-dependent and ERK pathways was strengthened by the observation that individual activated Rho GTPases failed to activate ERK $31,34,35,88$. Furthermore, ERK activation could not be detected upon coexpression of V12-Rac1, V12RhoG and V12-Cdc42Hs, whereas their associated expression elicited strong focus formation, up to $20 \%$ of that achieved with V12-Ras ${ }^{35}$. These data are consistent with studies using two activated Ras variants mutated in their effector sites (V12-G37-Ras and V12-C40-Ras, ${ }^{93}$ ). Both variants are defective in Raf-1 binding and subsequent ERK activation, but still trigger cellular transformation morphologically indistinguishable from that induced by constitutively activated Rho proteins. In addition, they both activate JNK, as do Rho family members, and their coexpression results in a synergistic cooperation of their transforming activities.

In conclusion, the recent literature indicates that Ras transformation is mediated by at least two distinct Raf/ERK-independent pathways, which might be controlled by Rho proteins (Figure 2). It now remains to determine which pathways might be involved in cell transformation. As previously mentioned, Rho proteins have been implicated in the control of numerous processes, and in particular, in the activation of MAP kinases distinct from 
ERK and in the reorganization of the actin cytoskeleton. The relevance of these biological processes in cell transformation is discussed in the next section.

\section{Signalling pathways downstream of Rho proteins involved in cell transformation}

\subsection{Rho-dependent activation of the JNK/SAPK pathway}

In addition to ERK, two novel classes of mammalian enzymes closely related to MAPK cascades have been identified. One class includes RK/p38 kinase ${ }^{94}$, which shares similarity with the yeast $S$. cerevisiae HOG1 kinase, involved in protection from hyperosmotic solutions (reviewed in ${ }^{95} ;{ }^{96,97}$. The second class is made up of a family of closely related kinases activated by cellular stress, either named stress-activated protein kinases (SAPKs) ${ }^{98}$ or c-jun N-terminal kinases (JNKs) ${ }^{99}$. The JNK/SAPK pathway is activated by a wide range of stimuli, such as protein synthesis inhibitors, inflammatory cytokines, changes in osmolarity, ultraviolet irradiation or heat shock. Once activated, JNK/SAPK proteins phosphorylate the transactivating domain of c-Jun, thereby modulating AP-1 activity and gene expression. JNK/SAPK proteins are also activated in growth-stimulated cells in a Ras-dependent but Raf-1-independent manner ${ }^{100}$. Additionally, recent reports showed that JNK/SAPK was associated with cell transformation ${ }^{101-104}$. Characterization of the kinases acting upstream of JNK/SAPK led to the identification of MEKK1 and PAK, homologues of the yeast STE11 and STE20 proteins, respectively ${ }^{105-109}$. The PAK family (p21-activated kinases) consists in three conserved members that were first isolated by their ability to be autophosphorylated and actived upon binding to GTP-bound Rac1 and $\mathrm{Cdc} 42 \mathrm{Hs}$ (reviewed in ${ }^{110}$ ). A direct implication of PAK1 in JNK/SAPK activation was observed using a constitutively activated PAK1 mutated protein in COS-7 cells ${ }^{111}$. These results led to the hypothesis that the JNK/SAPK pathway in mammals followed a cascade, in which Ras activates Rac1/Cdc42Hs, which in turn activates PAK, which phosphorylates MEKK1, eventually leading to the activation of JNK/SAPK. Accordingly, such a scheme suggested that the 
transforming potential of Rac1 and Cdc42Hs might be mediated by the JNK/SAPK pathway. However, recent results do not support this scheme.

First, whereas PAK1 interacts with components essential for Ras transformation, inhibition of PAK1 can be uncoupled from JNK but not ERK signalling. Two PAK1 mutants, R299-PAK which is catalytically inactive and L83L86R299-PAK, which is inactive and also unable to bind Rac1 or $\mathrm{Cdc} 42 \mathrm{Hs}$ were constructed to assess the effect of PAK1 on transformation ${ }^{112}$. Expression of R299-PAK inhibited Ras-mediated transformation in Rat-1 cells but not in NIH3T3 cells. It had no effect on Raf transforming activity but inhibited Ras- and Rac-dependent JNK activation. Expression of L83L86R299-PAK also inhibited Ras-dependent transformation but not JNK activation. Surprisingly, both mutants inhibited Ras-mediated ERK activation, suggesting that PAK might mediate signals from Ras to Raf.

Second, cooperation of Rac with Raf-CAAX in transformation, Rac/PAK interaction and JNK activation are all independent events ${ }^{113,114}$. Rac proteins mutated in their effector regions were assessed for their abilities to modulate JNK activation and transformation ${ }^{93}$. One mutant (V12H40-Rac1) was found to be defective in binding to PAK-3 and in JNK activation, but could still mediate transformation and bind POR1 (a Rac-binding protein involved in membrane ruffling ${ }^{115}$ ). Conversely, a second mutant (V12L37-Rac1), which bound PAK-3 but not POR1, could activate JNK but was defective in transformation. A third Rac effector mutant (L6143D-Rac1) was unable to cooperate with Raf-CAAX or interact with PAK but could still activate the JNK pathway.

In conclusion, although the direct implication of PAK in JNK activation remains controversial, it appears that Rac- and Cdc42Hs-dependent activation of JNK does not require PAK. Instead, recent reports indicate that other kinases such as MLK (Mixed Lineage Kinase) and MEKK might be implicated ${ }^{116-119}$. Nevertheless, PAK activity is required for Ras- but not Raf-dependent transformation. Demonstration of cooperation in cell transformation between activated PAK or JNK with Ras would unambiguously settle 
this point. However, it appears now that JNK and PAK activations are distinct from the Rac-controlled pathway acting in synergy with Raf in cell transformation (Figure 3). Whether JNK and PAK pathways are used by other Rho GTPases to cooperate with Raf remains to be investigated.

\subsection{The cytoskeleton and Rho proteins}

As mentioned earlier, oncogenic transformation is associated with changes in morphological characteristics of the cell, i.e. decreased anchorage dependent cell growth, invasiveness and reduction in cell contact inhibition, which appear controlled by Rho members. Various Rac1 and Cdc42Hs proteins mutated in their effector domains such as C40-Rac1 and C40-Cdc42Hs no longer interact with PAK and cannot activate the JNK pathway, but still induce cytoskeletal changes and G1 cell cycle progression ${ }^{120}$. Conversely, 37A-Rac1 can bind PAK and activates the JNK pathway, but no longer interacts with POR1, and does not induced lamellipodia formation, G1 cell cycle progression and cell transformation in association with Raf-CAAX ${ }^{113,120}$. In all instances, the formation of filopodia and lamellipodia induced by $\mathrm{Cdc} 42 \mathrm{Hs}$ and Rac1 was associated with their ability to cooperate with Raf in cell transformation. However, whether both events are functionally linked remains to be determined.

Recent published work suggest that the relationships between morphological characteristics and transformation are more complex than initially suspected. Tiam1, a $\mathrm{dbl}$-like protein, was isolated as a result of its role in invasion and metastasis in Tlymphoma ${ }^{4}$. Tiam1 expression was shown to induce Rac1-dependent extensive membrane ruffling in NIH3T3 cells, and to promote invasion in BW5147 T-lymphoma cells, like activated V12-Rac ${ }^{78}$. However, cells expressing Tiam1 variant C-682, which lacks all N-terminal sequences upstream of the dbl-like domain, are still highly tumourigenic in nude mice, even though they do not show morphological transformation and membrane ruffling. Expression of Tiam1 variant N-385, which contains the first 385 amino acids but lacks the GEF domain, does not exhibit a tumourigenic effect in nude 
mice or invasion in NIH3T3 cells, but still induces invasion when expressed in Tlymphoma cells. Thus, although Tiam1 activates Rac1 both in vitro and in vivo, its ability to elicit cell invasion does not require Rac1-dependent ruffling, and in specific cells, is even independent of Rac1 activation.

A second example of uncoupling between cytoskeletal rearrangements and cell transformation was established from experiments with $\mathrm{Cdc} 42 \mathrm{Hs}{ }^{80}$. Low levels of $\mathrm{N} 17-$ Cdc42Hs expression were shown to be sufficient to inhibit Ras and Raf-CAAX transformation, but did not reduce the formation of filopodia. Similar observations have been reported for Rac1, where L61V31 and V12L37 variants partially or completely inhibited lamellipodium formation, respectively, but only mildly suppressed Raf-CAAXinduced cell transformation ${ }^{114}$. Thus, the pathways leading to lamellipodia and filopodia formation appear distinct from the one leading to serum- and anchorage-independent cell growth involved in Ras- and Raf-mediated transformation.

A third indirect set of experiments dealing with PAK activity suggests that morphological changes might be dispensable for cooperation of Rho proteins in transformation. Indeed, as previously mentioned, PAK activation is thought to be required for Ras but not Raf-CAAX transformation ${ }^{112}$. A GST-PAK fusion, constitutively active in vitro ${ }^{121}$, rapidly elicited filopodia and lamellipodia formation ${ }^{122}$, similar to the effects observed upon introduction of $\mathrm{V} 12-\mathrm{Cdc} 42 \mathrm{Hs}$ and $\mathrm{V} 12-\mathrm{Rac} 1$. This was confirmed by transfecting HeLa cells and fibroblasts with plasmids encoding constitutively active PAK, mutated at its autophosphorylation sites ${ }^{123}$. Such expression caused loss of stress fibres and focal adhesions. These effects were also similar to those observed upon expression of V12-Cdc42Hs or V12-Rac1. Therefore both reports indicate that PAK activity might be necessary for $\mathrm{Cdc42Hs-and} \mathrm{Rac1-dependent} \mathrm{actin} \mathrm{reorganization.} \mathrm{If} \mathrm{so,} \mathrm{the} \mathrm{observation}$ that PAK activity is dispensable for Raf-CAAX focus forming activity suggests that morphological modifications delineate a pathway distinct from the one involved in transformation (Figure 3). 
In conclusion, although overall changes in cellular morphology are undoubtedly crucial for the process of cell transformation, there is still a lack of evidence that Rho proteins use pathways leading to cytoskeletal reorganization to cooperate in cell transformation.

\section{Rho proteins and apoptosis}

Programmed cell death (also termed apoptosis) is a conserved active cellular mechanism involved in the control of many normal physiological processes, such as development and differentiation, or in pathological aspects such as tumourigenesis ${ }^{124,} 125$. Apoptosis is characterized by cell membrane blebbing, phosphatidylserine externalization, cytoskeletal disruption, and nuclear chromatin condensation (reviewed in ${ }^{126}$ ). At later stages, the cytoplasm and nucleus become compartmentalised and form apoptotic bodies, which are submitted to phagocytosis by neighbouring cells. The resulting action of two types of signals is required for a cell to commit to apoptosis: i) a number of external signals have been characterized, such as binding of specific ligands to receptors of the nerve growth factor family, ionising radiation, ceramides, cell-to-cell and cell-to-extracellular matrix contacts or serum starvation ${ }^{127}$; ii) internal signals are also critical, including cell lineage, cell cycle stage, proto-oncogene expression, and metabolic state. Both types of signals also participate in other processes, such as cell proliferation and transformation.

Ras proteins were recently shown to inhibit apoptosis by selective activation of survival pathways. In fibroblasts, Ras expression suppresses c-myc-induced apoptosis through the activation of $\mathrm{PI} 3 \mathrm{~K}$ and the serine/threonine kinase PKB/Akt ${ }^{128}$. Expression of Ras in epithelial cells, which normally undergo apoptosis upon detachment from the extracellular matrix, inhibits programmed cell death through activation of $\mathrm{PI} I 3 \mathrm{~K}^{129}$. Interestingly, opposing effects have been described in other cell systems. For example, Ras inhibition blocks Fas- or ceramide-induced apoptosis in Jurkat T-cells ${ }^{130}$, and p120GAP gene inactivation in mice induces a dramatic apoptosis of neurons in the 
developing brain ${ }^{131}$. Thus, opposed signals such as cell proliferation, differentiation and apoptosis can be conveyed through the activation of the same molecular switch, i.e. the Ras protein. This is illustrated by the activation of Ras in both IL-2 dependent proliferation and apoptosis of T cells ${ }^{132}$. Taking into account the regulatory crosstalk between Ras and Rho pathways, it was of importance to address the role of Rho GTPases in the process of programmed cell death.

It was first observed that overexpression of Rho proteins enhances apoptosis in serum deprived murine NIH3T3 fibroblasts ${ }^{5}$. Such apoptotic activation is related to the production of ceramides ${ }^{133}$, which are sphingolipid breakdown products that function as inhibitors of cell growth ${ }^{134,135}$ and inducers of apoptosis ${ }^{136,137}$. Serum-starved but not serum-fed RhoA-overexpressing NIH3T3 cells show an increase in the intracellular level of ceramide, while no change could be detected in control cells or Ras expressing cells. In all situations, activation of ceramide production is associated with apoptosis. Addition of permeable ceramide has no apoptotic effect on control NIH3T3 cells, whereas it is sufficient to induce apoptosis in RhoA-expressing NIH3T3 cells even in the presence of $10 \%$ serum. This led to the conclusion that Rho proteins control two complementary signals involved in apoptosis ${ }^{138}$ : one pathway leads to the production of ceramide, and is involved in the progression towards apoptosis and a second pathway, possibly tye JNK/SAPK cascade, which makes the cell competent to interprete the ceramidedependent apoptotic signal ${ }^{139}$. Recent reports strengthen this hypothesis. First, in T lymphoma cells, apoptosis requires the activation of Ras, Rac and RhoA proteins ${ }^{140,141 .}$ This points to the paradoxical role of the Ras/Rho pathway, which may control cell proliferation or programmed cell death, depending on internal or external co-signals. Then, activation of Jurkat cells via the Fas receptor or synthetic ceramides leads to a Ras- and Rac-dependent stimulation of JNK and RK/p38 ${ }^{142}$. The functional link between this pathway and apoptosis was established using transdominant inhibitory Ras, Rac and JNK, and a specific pharmacological blocker of RK/p38 kinase. Activation of JNK and 
RK/p38 was followed by phosphorylation of the transcriptional factor GADD153. Although the effect of such phosphorylation upon Fas receptor triggering is unknown, GADD153 [also termed CHOP or growth arrest and DNA damage-inducible gene 153] might inhibit C/EBP binding to DNA or redirect GADD153-C/EBP heterodimers to other DNA target sequences thereby modifying gene expression ${ }^{143,144}$. The implication of the Rho family in apoptosis has been recently extended to others members such as RhoA, whose activity is required for thrombin-induced apoptosis of cultured neurons and astrocytes ${ }^{145}$, and Rac2, whose constitutive activation enhances apoptosis in the thymus of transgenic mice ${ }^{146}$.

In conclusion, Rho overexpression appears sufficient to render cells prone to initiate the apoptotic process. In contrast, Ras overexpression is not sufficient, although its activity is required for the apoptotic signal (Figure 4). According to this scheme, one could speculate that the apparent low focus forming activity of Rho proteins might be explained by a high apoptotic index of Rho expressing cells. A cooperation with Ras or Raf-CAAX and Rho proteins in cell transformation might therefore be explained by a change in internal signals redirecting apoptotic signals towards proliferation.

\section{Concluding remarks}

The Rho family of GTPases participate in the control of many basic physiological aspects of the cell, e.g. cell growth, differentiation, motility or apoptosis. The characterization of biological activities of the Rho proteins was mainly investigated by expressing mutated proteins. However, the use of such mutants suffers several limitations: i) Inasmuch as some regulatory proteins are able to control the activity of distinct GTPases, expression of N17-mutated proteins might inhibit more than one specific GTPase. ii) taking into account the similarity in the effector domain of several GTPases, one could expect illegitimate activation of additional pathways upon overexpression of a given protein: Expression of activated RK/p38, but not p46-JNK, p44ERK or p70-S6K, also blocked NIH3T3 cells in $\mathrm{G}_{1} / \mathrm{S}^{33}$. In the same cell line, Cdc42Hs elicits RK/p38 activation and $\mathrm{G}_{1} / \mathrm{S}$ arrest in NIH3T3 cells, whereas Rac expression does 
not cause cell cycle arrest, although activating RK/p38 in situ. This suggests that the pattern of kinase activation in vivo might differ from what observed from kinase assays. iii) specific mutations in the effector domain were reported to differentially decrease in vitro or in levuro the affinity for particular target proteins. However, the effective loss of a specific binding within the cell (i.e. the absence of any activation) remains to be settled. iv) Expression of active and inhibitory mutated proteins sometimes produce identical phenotypic effects. Wild-type, N17- or $\mathrm{V} 12-\mathrm{Cdc}_{2} \mathrm{Hs}$ were reported to inhibit $\mathrm{G}_{1} / \mathrm{S}$ progression to the same extent ${ }^{33}$, and expression of N19-RhoA was shown to promote stress fibres formation ${ }^{81}$.

Despite these limitations, it emerges from this survey that Rho proteins control multiple pathways that cooperate in cell transformation. Two pathways are now firmly established : one is controlled by RhoG and Rac, and modulates cell contact inhibition, while the other is governed by $\mathrm{Cdc} 42 \mathrm{Hs}$ and RhoA, and affects anchorage-independent cell growth. The precise molecular mechanisms underlying these biological features is still debated. The implication of other pathways is also suspected, although they remained to be characterized. Additionally, only a limited number of Rho family members have been so far studied in detail, which leaves open a wide range of unknown pathways that might also influence physiological parameters critical for cell transformation. Finally, recent data support a crucial function of Rho proteins in the signalling of the apoptotic signal, whose perturbation constitutes an alternative for a cell to escape growth control.

In all instances, activities of Rho proteins appear tightly linked each to one another, according to a complex network of regulatory crosstalk. Deciphering of such network, and of relationships bridging Ras and Rho proteins will prove valuable for a better understanding of tumourigenesis.

\section{Acknowledgements}

I wish to thank C. Gauthier, P. Roux, N. Taylor for helpful discussions and comments on the manuscript. This work was supported by institutional grants from the 
INSERM, the CNRS and the Universite de Montpellier II, and grants from the Association pour la Recherche contre le Cancer, the Ligue Nationale Contre le Cancer and the CNRS (programme "Biologie Cellulaire").

\section{References}

1. Ridley AJ. Membrane ruffling and signal transduction. Bioessays 1994; 16:321-7.

2. Aepfelbacher M, Vauti F, Weber PC, Glomset JA. Spreading of differentiating human monocytes is associated with a major increase in membrane-bound CDC42. Proc Natl Acad Sci USA 1994; 91:4263-7.

3. Hirata K, Kikuchi A, Sasaki T, Kuroda S, Kaibuchi K, Matsuura Y, Seki H, Saida K, Takai Y. Involvement of rho p21 in the GTP-enhanced calcium ion sensitivity of smooth muscle contraction. J Biol Chem 1992; 267:8719-22.

4. Habets GG, Scholtes EH, Zuydgeest D, van der Kammen RA, Stam JC, Berns A, Collard JG. Identification of an invasion-inducing gene, Tiam-1, that encodes a protein with homology to GDP-GTP exchangers for Rho-like proteins. Cell 1994; 77:537-49.

5. Jimenez B, Arends M, Esteve P, Perona R, Sanchez R, Ramon Y, S. C, Wyllie A, Lacal JC. Induction of apoptosis in NIH3T3 cells after serum deprivation by overexpression of rho-p21, a GTPase protein of the ras superfamily. Oncogene 1995; 10:811-6.

6. $\quad$ Madaule P, Axel R. A novel ras-related gene family. Cell 1985; 41:31-40.

7. Chardin $\mathrm{P}$, Madaule $\mathrm{P}$, Tavitian A. Coding sequences of human rho cDNAs clone 6 and clone 9. Nucleic Acids Res 1988; 16:2717.

8. Murphy C, Saffrich R, Grummt M, Gournier H, Rybin V, Rubino M, Auvinen P, Lutcke A, Parton RG, Zerial M. Endosome dynamics regulated by a Rho protein. Nature 1996; 384:427-32.

9. Foster R, Hu KQ, Lu Y, Nolan KM, Thissen J, Settleman J. Identification of a novel human Rho protein with unusual properties: GTPase deficiency and in vivo farnesylation. Mol Cell Biol 1996; 16:2689-99.

10. Murphy AM, Montell DJ. Cell type-specific roles for Cdc42, Rac, and RhoL in Drosophila oogenesis. J Cell Biol 1996; 133:617-30.

11. Didsbury J, Weber RF, Bokoch GM, Evans T, Synderman R. rac, a novel rasrelated family of proteins that are botulinum toxin substrates. J Biol Chem 1989; 264:16378-82.

12. Courjal $F$, Chuchana $P$, Theillet $C$, Fort $P$. Structure and chromosomal assignment to $22 q 12$ and 17 qter of the ras-related Rac2 and Rac3 human genes. Genomics 1997; 44:(in press).

13. Haataja L, Groffen J, Heisterkamp N. Characterization of RAC3, a novel member of the rho family. J Biol Chem 1997; 272:20384-8.

14. Vincent S, Jeanteur P, Fort P. Growth-regulated expression of rhoG, a new member of the ras homolog gene family. Mol Cell Biol 1992; 12:3138-48.

15. Shinjo K, Koland JG, Hart MJ, Narasimhan V, Johnson DI, Evans T, Cerione RA. Molecular cloning of the gene for the human placental GTP-binding protein Gp (G25K): identification of this GTP-binding protein as the human homolog of the yeast cell-divisioncycle protein CDC42. Proc Natl Acad Sci USA 1990; 87:9853-7.

16. Drivas GT, Shih A, Coutavas E, Rush MG, D'Eustachio P. Characterization of four novel ras-like genes expressed in a human teratocarcinoma cell line. Mol Cell Biol 1990; 10:1793-8.

17. Dallery E, Galiegue-Zouitina S, Collyn-d'Hooghe M, Quief S, Denis C, Hildebrand MP, Lantoine D, Deweindt C, Tilly H, Bastard C. TTF, a gene encoding a novel small G 
protein, fuses to the lymphoma- associated LAZ3 gene by $t(3 ; 4)$ chromosomal translocation. Oncogene 1995; 10:2171-8.

18. Ridley AJ, Paterson HF, Johnston CL, Diekmann D, Hall A. The small GTPbinding protein rac regulates growth factor-induced membrane ruffling. Cell 1992; 70:40110.

19. Ridley AJ, Hall A. The small GTP-binding protein rho regulates the assembly of focal adhesions and actin stress fibers in response to growth factors. Cell 1992; 70:38999.

20. Flescher EG, Madden K, Snyder M. Components required for cytokinesis are important for bud site selection in yeast. J Cell Biol 1993; 122:373-86.

21. Luo L, Liao YJ, Jan LY, Jan YN. Distinct morphogenetic functions of similar small GTPases: Drosophila Drac1 is involved in axonal outgrowth and myoblast fusion. Genes Dev 1994; 8:1787-802.

22. Abo A, Pick E, Hall A, Totty N, Teahan CG, Segal AW. Activation of the NADPH oxidase involves the small GTP-binding protein p21rac1. Nature 1991; 353:668-70.

23. Abo A, Webb MR, Grogan A, Segal AW. Activation of NADPH oxidase involves the dissociation of p21rac from its inhibitory GDP/GTP exchange protein (rhoGDI) followed by its translocation to the plasma membrane. Biochem J 1994; 3:585-91.

24. Knaus UG, Heyworth PG, Evans T, Curnutte JT, Bokoch GM. Regulation of phagocyte oxygen radical production by the GTP-binding protein Rac 2. Science 1991; 254:1512-5.

25. Knaus UG, Heyworth PG, Kinsella BT, Curnutte JT, Bokoch GM. Purification and characterization of Rac 2. A cytosolic GTP-binding protein that regulates human neutrophil NADPH oxidase. J Biol Chem 1992; 267:23575-82.

26. Adams AE, Johnson DI, Longnecker RM, Sloat BF, Pringle JR. CDC42 and CDC43, two additional genes involved in budding and the establishment of cell polarity in the yeast Saccharomyces cerevisiae. J Cell Biol 1990; 111:131-42.

27. Johnson DI, Pringle JR. Molecular characterization of CDC42, a Saccharomyces cerevisiae gene involved in the development of cell polarity. J Cell Biol 1990; 111:143-52.

28. Stowers L, Yelon D, Berg LJ, Chant J. Regulation of the polarization of T cells toward antigen-presenting cells by Ras-related GTPase CDC42. Proc Natl Acad Sci USA 1995; 92:5027-31.

29. Nobes CD, Hall A. Rho, rac, and cdc42 GTPases regulate the assembly of multimolecular focal complexes associated with actin stress fibers, lamellipodia, and filopodia. Cell 1995; 81:53-62.

30. Olson MF, Ashworth A, Hall A. An essential role for rho, rac, and cdc42 GTPases in cell cycle progression through G1. Science 1995; 269:1270-2.

31. Hill CS, Wynne J, Treisman R. The rho family GTPases RhoA, rac1, and CDC42Hs regulate transcriptional activation by SRF. Cell 1995; 81:1159-70.

32. Dutartre H, Davoust J, Gorvel J-P, Chavrier P. Cytokinesis arrest and redistribution of actin-cytoskeleton regulatory components in cells expressing the Rho GTPase Cdc42Hs. J Cell Sci 1996; 109:367-77.

33. Molnar A, Theodoras AM, Zon LI, Kyriakis JM. Cdc42Hs, but not Rac1, inhibits serum-stimulated cell cycle progression at G1/S through a mechanism requiring p38/RK. J Biol Chem 1997; 272:13229-35.

34. Coso OA, Chiariello M, Yu JC, Teramoto H, Crespo P, Xu NG, Miki T, Gutkind JS. The small GTP-Binding proteins rac1 and cdc42 regulate the activity of the JNK/SAPK signaling pathway. Cell 1995; 81:1137-46.

35. Roux P, Gauthier-Rouvière $C$, Doucet-Brutin S, Fort P. The small GTPases Cdc42Hs, Rac1 and RhoG delineate Raf-independent pathways that cooperate to transform NIH3T3 cells. Current Biol 1997; 7:629-37. 
36. Fukumoto $\mathrm{Y}$, Kaibuchi K, Hori $\mathrm{Y}$, Fujioka H, Araki S, Ueda T, Kikuchi A, Takai $\mathrm{Y}$. Molecular cloning and characterization of a novel type of regulatory protein (GDI) for the rho proteins, ras p21-like small GTP-binding proteins. Oncogene 1990; 5:1321-8.

37. Adra CN, Ko J, Leonard D, Wirth LJ, Cerione RA, Lim B. Identification of a novel protein with GDP dissociation inhibitor activity for the ras-like proteins $\mathrm{CDC} 42 \mathrm{Hs}$ and rac I. Genes Chromosomes Cancer 1993; 8:253-61.

38. Scherle P, Behrens T, Staudt LM. Ly-GDI, a GDP-dissociation inhibitor of the RhoA GTP-binding protein, is expressed preferentially in lymphocytes. Proc Natl Acad Sci USA 1993; 90:7568-72.

39. Adra CN, Manor D, Ko JL, Zhu S, Horiuchi T, Van Aelst L, Cerione RA, Lim B. RhoGDIgamma: a GDP-dissociation inhibitor for Rho proteins with preferential expression in brain and pancreas. Proc Natl Acad Sci USA 1997; 94:4279-84.

40. Zalcman G, Closson V, Camonis J, Honore N, Rousseau-Merck MF, Tavitian A, Olofsson B. RhoGDI-3 is a new GDP dissociation inhibitor (GDI). Identification of a noncytosolic GDI protein interacting with the small GTP-binding proteins RhoB and RhoG. J Biol Chem 1996; 271:30366-74.

41. Settleman J, Narasimhan V, Foster LC, Weinberg RA. Molecular cloning of cDNAs encoding the GAP-associated protein p190: implications for a signaling pathway from ras to the nucleus. Cell 1992; 69:539-49.

42. Burbelo PD, Miyamoto S, Utani A, Brill S, Yamada KM, Hall A, Yamada Y. p190-B, a new member of the Rho GAP family, and Rho are induced to cluster after integrin crosslinking. J Biol Chem 1995; 270:30919-26.

43. Garrett MD, Major GN, Totty N, Hall A. Purification and N-terminal sequence of the p21rho GTPase-activating protein, rho GAP. Biochem J 1991; 276:833-6.

44. Heisterkamp N, Kaartinen V, van Soest S, Bokoch GM, Groffen J. Human ABR encodes a protein with GAPrac activity and homology to the DBL nucleotide exchange factor domain. J Biol Chem 1993; 268:16903-6.

45. Heisterkamp N, Stephenson JR, Groffen J, Hansen PF, de Klein A, Bartram CR, Grosveld G. Localization of the c-ab1 oncogene adjacent to a translocation break point in chronic myelocytic leukaemia. Nature 1983; 306:239-42.

46. Hart MJ, Shinjo K, Hall A, Evans T, Cerione RA. Identification of the human platelet GTPase activating protein for the CDC42Hs protein. J Biol Chem 1991; 266:20840-8.

47. Barfod ET, Zheng Y, Kuang WJ, Hart MJ, Evans T, Cerione RA, Ashkenazi A. Cloning and expression of a human CDC42 GTPase-activating protein reveals a functional SH3-binding domain. J Biol Chem 1993; 268:26059-62.

48. Cicchetti P, Ridley AJ, Zheng Y, Cerione RA, Baltimore D. 3BP-1, an SH3 domain binding protein, has GAP activity for Rac and inhibits growth factor-induced membrane ruffling in fibroblasts. EMBO J 1995; 14:3127-35.

49. Cooper JA, Kashishian A. In vivo binding properties of $\mathrm{SH} 2$ domains from GTPase-activating protein and phosphatidylinositol 3-kinase. Mol Cell Biol 1993; 13:173745.

50. Hall C, Monfries C, Smith P, Lim HH, Kozma R, Ahmed S, Vanniasingham V, Leung T, Lim L. Novel human brain cDNA encoding a 34,000 Mr protein n-chimaerin, related to both the regulatory domain of protein kinase $C$ and $B C R$, the product of the breakpoint cluster region gene. J Mol Biol 1990; 211:11-6.

51. Tribioli C, Droetto S, Bione S, Cesareni G, Torrisi MR, Lotti LV, Lanfrancone L, Toniolo D, Pelicci P. An X chromosome-linked gene encoding a protein with characteristics of a rhoGAP predominantly expressed in hematopoietic cells. Proc Natl Acad Sci USA 1996; 93:695-9.

52. Park SH, Weinberg RA. A putative effector of Ral has homology to Rho/Rac GTPase activating proteins. Oncogene 1995; 11:2349-55. 
53. Jullien-Flores $V$, Dorseuil $O$, Romero $F$, Letourneur F, Saragosti S, Berger R, Tavitian A, Gacon G, Camonis JH. Bridging Ral GTPase to Rho pathways. RLIP76, a Ral effector with CDC42/Rac GTPase-activating protein activity. J Biol Chem 1995; 270:22473-7.

54. Reinhard J, Scheel AA, Diekmann D, Hall A, Ruppert C, Bahler M. A novel type of myosin implicated in signalling by rho family GTPases. EMBO J 1995; 14:697-704.

55. Wirth JA, Jensen KA, Post PL, Bement WM, Mooseker MS. Human myosin-IXb, an unconventional myosin with a chimerin-like rho/rac GTPase-activating protein domain in its tail. J Cell Sci 1996; 109:653-61.

56. Hildebrand JD, Taylor JM, Parsons JT. An SH3 domain-containing GTPaseactivating protein for Rho and Cdc42 associates with focal adhesion kinase. Mol Cell Biol 1996; 16:3169-78.

57. Brill S, Li S, Lyman CW, Church DM, Wasmuth JJ, Weissbach L, Bernards A, Snijders AJ. The Ras GTPase-activating-protein-related human protein IQGAP2 harbors a potential actin binding domain and interacts with calmodulin and Rho family GTPases. Mol Cell Biol 1996; 16:4869-78.

58. Manser E, Leung T, Monfries C, Teo M, Hall C, Lim L. Diversity and versatility of GTPase activating proteins for the $\mathrm{p} 21$ rho subfamily of ras $\mathrm{G}$ proteins detected by a novel overlay assay. J Biol Chem 1992; 267:16025-8.

59. Ridley AJ, Self AJ, Kasmi F, Paterson HF, Hall A, Marshall CJ, Ellis C. rho family GTPase activating proteins $\mathrm{p} 190$, bcr and rhoGAP show distinct specificities in vitro and in vivo. EMBO J 1993; 12:5151-60.

60. Ron D, Zannini M, Lewis M, Wickner RB, Hunt LT, Graziani G, Tronick SR, Aaronson SA, Eva A. A region of proto-dbl essential for its transforming activity shows sequence similarity to a yeast cell cycle gene, $\mathrm{CDC} 24$, and the human breakpoint cluster gene, bcr. New Biol 1991; 3:372-9.

61. Hart MJ, Eva A, Evans T, Aaronson SA, Cerione RA. Catalysis of guanine nucleotide exchange on the $\mathrm{CDC} 42 \mathrm{Hs}$ protein by the $\mathrm{dbl}$ oncogene product. Nature 1991a; 354:311-4.

62. Hart MJ, Eva A, Zangrilli D, Aaronson SA, Evans T, Cerione RA, Zheng Y. Cellular transformation and guanine nucleotide exchange activity are catalyzed by a common domain on the dbl oncogene product. J Biol Chem 1994; 269:62-5.

63. Zheng $\mathrm{Y}$, Cerione R, Bender A. Control of the yeast bud-site assembly GTPase Cdc42. Catalysis of guanine nucleotide exchange by Cdc24 and stimulation of GTPase activity by Bem3. J Biol Chem 1994; 269:2369-72.

64. Katzav S, Martin-Zanca D, Barbacid M. vav, a novel human oncogene derived from a locus ubiquitously expressed in hematopoietic cells. EMBO J 1989; 8:2283-90.

65. Horii Y, Beeler JF, Sakaguchi K, Tachibana M, Miki T. A novel oncogene, ost, encodes a guanine nucleotide exchange factor that potentially links Rho and Rac signaling pathways. EMBO J 1994; 13:4776-86.

66. Miki T, Smith CL, Long JE, Eva A, Fleming TP. Oncogene ect2 is related to regulators of small GTP-binding proteins. Nature 1993; 362:462-5.

67. Chan AM, McGovern ES, Catalano G, Fleming TP, Miki T. Expression cDNA cloning of a novel oncogene with sequence similarity to regulators of small GTP-binding proteins. Oncogene 1994; 9:1057-63.

68. Pasteris NG, Cadle A, Logie LJ, Porteous ME, Schwartz CE, Stevenson RE, Glover TW, Wilroy RS, Gorski JL. Isolation and characterization of the faciogenital dysplasia (Aarskog-Scott syndrome) gene: a putative Rho/Rac guanine nucleotide exchange factor. Cell 1994; 79:669-78.

69. Whitehead I, Kirk H, Kay R. Retroviral transduction and oncogenic selection of a cDNA encoding Dbs, a homolog of the Dbl guanine nucleotide exchange factor. Oncogene 1995; 10:713-21. 
70. Toksoz D, Williams DA. Novel human oncogene lbc detected by transfection with distinct homology regions to signal transduction products. Oncogene 1994; 9:621-8.

71. Whitehead I, Kirk H, Tognon C, Trigo-Gonzalez G, Kay R. Expression cloning of Ifc, a novel oncogene with structural similarities to guanine nucleotide exchange factors and to the regulatory region of protein kinase C. J Biol Chem 1995; 270:18388-95.

72. Whitehead IP, Khosravi-Far R, Kirk H, Trigo-Gonzalez G, Der CJ, Kay R. Expression cloning of Isc, a novel oncogene with structural similarities to the Dbl family of guanine nucleotide exchange factors. J Biol Chem 1996; 271:18643-50.

73. Cerione RA, Zheng Y. The Dbl family of oncogenes. Curr Opin Cell Biol 1996; 8:216-22.

74. Avraham $\mathrm{H}$, Weinberg RA. Characterization and expression of the human rhoH12 gene product. Mol Cell Biol 1989; 9:2058-66.

75. Perona R, Esteve P, Jimenez B, Ballestero RP, Ramon y Cajal S, Lacal JC. Tumorigenic activity of rho genes from Aplysia californica. Oncogene 1993; 8:1285-92.

76. Prendergast GC, Khosravi-Far R, Solski PA, Kurzawa H, Lebowitz PF, Der CJ. Critical role of Rho in cell transformation by oncogenic Ras. Oncogene 1995; 10:2289-96.

77. Qiu R-G, Chen J, Kirn D, McCormick F, Symons M. An essential role for Rac in Ras transformation. Nature 1995a; 374:457-9.

78. van Leeuwen FN, van der Kammen RA, Habets GG, Collard JG. Oncogenic activity of Tiam1 and Rac1 in NIH3T3 cells. Oncogene 1995; 11:2215-21.

79. Michiels F, Habets GG, Stam JC, van der Kammen RA, Collard JG. A role for Rac in Tiam1-induced membrane ruffling and invasion. Nature 1995; 375:338-40.

80. Qiu RG, Abo A, McCormick F, Symons M. Cdc42 regulates anchorageindependent growth and is necessary for Ras transformation. Mol Cell Biol 1997; 17:3449-58.

81. Qiu RG, Chen J, McCormick F, Symons M. A role for Rho in Ras transformation. Proc Natl Acad Sci USA 1995b; 92:11781-5.

82. Tapon N, Hall A. Rho, Rac and Cdc42 GTPases regulate the organization of the actin cytoskeleton. Curr Opin Cell Biol 1997; 9:86-92.

83. Machesky L, Hall A. Rho: a connection between membrane receptor signalling and the cytoskeleton. Trends Cell Biol 1996; 6:304-10.

84. Allen WE, Jones GE, Pollard JW, Ridley AJ. Rho, Rac and Cdc42 regulate actin organization and cell adhesion in macrophages. J Cell Science 1997; 110:707-20.

85. Bar-Sagi D, Feramisco JR. Induction of membrane ruffling and fluid-phase pinocytosis in quiescent fibroblasts by ras proteins. Science 1986; 233:1061-8.

86. Pronk GJ, de Vries-Smits AM, Ellis C, Bos JL. Complex formation between the p21ras GTPase-activating protein and phosphoproteins p62 and p190 is independent of p21ras signalling. Oncogene 1993; 8:2773-80.

87. Chang EC, Barr M, Wang Y, Jung V, Xu HP, Wigler MH. Cooperative interaction of S. pombe proteins required for mating and morphogenesis. Cell 1994; 79:131-41.

88. Khosravi-Far R, Solski PA, Clark GJ, Kinch MS, Der CJ. Activation of Rac1, RhoA, and mitogen-activated protein kinases is required for Ras transformation. Mol Cell Biol 1995; 15:6443-53.

89. Wang DZ, Nur-E-Kamal MS, Tikoo A, Montague W, Maruta H. The GTPase and Rho GAP domains of p190, a tumor suppressor protein that binds the Mr 120,000 Ras GAP, independently function as anti-Ras tumor suppressors. Cancer Res 1997; 57:247884.

90. Marshall CJ. Ras effectors. Curr Opin Cell Biol 1996; 8:197-204.

91. Marais R, Marshall CJ. Control of the ERK MAP kinase cascade by Ras and Raf. Cancer Surv 1996; 27:101-25.

92. Leevers SJ, Paterson HF, Marshall CJ. Requirement for Ras in Raf activation is overcome by targeting Raf to the plasma membrane. Nature 1994; 369:411-4. 
93. Khosravi-Far R, White MA, Westwick JK, Solski PA, Chrzanowska- Wodnicka M, Van Aelst L, Wigler MH, Der CJ. Oncogenic Ras activation of Raf/mitogen-activated protein kinase- independent pathways is sufficient to cause tumorigenic transformation. Mol Cell Biol 1996; 16:3923-33.

94. Han J, Lee JD, Bibbs L, Ulevitch RJ. A MAP kinase targeted by endotoxin and hyperosmolarity in mammalian cells. Science 1994; 265:808-11.

95. Herskowitz I. MAP kinase pathway in yeast: fore mating and more. Cell 1995; 80:187-97.

96. Cano E, Mahadevan LC. Parallel signal processing among mammalian MAPKs. Trends Biochem Sci 1995; 20:117-22.

97. Kyriakis JM, Avruch J. Protein kinase cascades activated by stress and inflammatory cytokines. Bioessays 1996; 18:567-77.

98. Kyriakis JM, Banerjee P, Nikolakaki E, Dai T, Rubie EA, Ahmad MF, Avruch J, Woodgett JR. The stress-activated protein kinase subfamily of c-Jun kinases. Nature 1994; 369:156-60.

99. Derijard B, Hibi M, Wu IH, Barrett T, Su B, Deng T, Karin M, Davis RJ. JNK1: a protein kinase stimulated by UV light and Ha-Ras that binds and phosphorylates the C-Jun activation domain. Cell 1994; 76:1025-37.

100. Minden A, Lin A, McMahon M, Lange CC, Derijard B, Davis RJ, Johnson GL, Karin M. Differential activation of ERK and JNK mitogen-activated protein kinases by Raf-1 and MEKK. Science 1994; 266:1719-23.

101. Raitano AB, Halpern JR, Hambuch TM, Sawyers CL. The Bcr-Abl leukemia oncogene activates Jun kinase and requires Jun for transformation. Proc Natl Acad Sci USA 1995; 92:11746-50.

102. Galley Y, Hagens G, Glaser I, Davis W, Eichhorn M, Dobbelaere D. Jun NH2terminal kinase is constitutively activated in $T$ cells transformed by the intracellular parasite Theileria parva. Proc Natl Acad Sci USA 1997; 94:5119-24.

103. Xu X, Heidenreich O, Kitajima I, McGuire K, Li Q, Su B, Nerenberg M. Constitutively activated JNK is associated with HTLV-1 mediated tumorigenesis. Oncogene 1996; 13:135-42.

104. Rodrigues GA, Park M, Schlessinger J. Activation of the JNK pathway is essential for transformation by the Met oncogene. EMBO J 1997; 16:2634-45.

105. Lange-Carter CA, Pleiman CM, Gardner AM, Blumer KJ, Johnson GL. A divergence in the MAP kinase regulatory network defined by MEK kinase and Raf. Science 1993; 260:315-9.

106. Bagrodia S, Derijard B, Davis RJ, Cerione RA. Cdc42 and PAK-mediated signaling leads to Jun kinase and p38 mitogen- activated protein kinase activation. J Biol Chem 1995; 270:27995-8.

107. Teo M, Manser E, Lim L. Identification and molecular cloning of a p21cdc42/rac1activated serine/threonine kinase that is rapidly activated by thrombin in platelets. $\mathrm{J}$ Biol Chem 1995; 270:26690-7.

108. Martin GA, Bollag G, McCormick F, Abo A. A novel serine kinase activated by rac1/CDC42Hs-dependent autophosphorylation is related to PAK65 and STE20. EMBO J 1995; 14:1970-8.

109. Manser E, Chong C, Zhao ZS, Leung T, Michael G, Hall C, Lim L. Molecular cloning of a new member of the p21-Cdc42/Rac-activated kinase (PAK) family. J Biol Chem 1995; 270:25070-8.

110. Lim L, Manser E, Leung T, Hall C. Regulation of phosphorylation pathways by $p 21$ GTPases. The p21 Ras- related Rho subfamily and its role in phosphorylation signalling pathways. Eur J Biochem 1996; 242:171-85.

111. Brown JL, Stowers L, Baer M, Trejo J, Coughlin S, Chant J. Human Ste20 homologue hPAK1 links GTPases to the JNK MAP kinase pathway. Curr Biol 1996; 6:598-605. 
112. Tang Y, Chen Z, Ambrose D, Liu J, Gibbs JB, Chernoff J, Field J. Kinase-deficient Pak1 mutants inhibit Ras transformation of Rat-1 fibroblasts. Mol Cell Biol 1997; 17:445464.

113. Joneson $T$, McDonough M, Bar-Sagi D, Van Aelst L. RAC regulation of actin polymerization and proliferation by a pathway distinct from Jun kinase. Science 1996; 274:1374-6.

114. Westwick JK, Lambert QT, Clark GJ, Symons M, Van Aelst L, Pestell RG, Der CJ. Rac regulation of transformation, gene expression, and actin organization by multiple, PAK-independent pathways. Mol Cell Biol 1997; 17:1324-35.

115. Van Aelst L, Joneson T, Bar-Sagi D. Identification of a novel Rac1 interacting protein involved in membrane ruffling. EMBO J 1996; 15:3778-86.

116. Teramoto $H$, Coso OA, Miyata H, Igishi T, Miki T, Gutkind JS. Signaling from the small GTP-binding proteins Rac1 and Cdc42 to the c-Jun N-terminal kinase/stressactivated protein kinase pathway. A role for mixed lineage kinase 3/protein-tyrosine kinase 1, a novel member of the mixed lineage kinase family. J Biol Chem 1996; 271:27225-8.

117. Tibbles LA, Ing YL, Kiefer F, Chan J, Iscove N, Woodgett JR, Lassam NJ. MLK-3 activates the SAPK/JNK and p38/RK pathways via SEK1 and MKK3/6. EMBO J 1996; 15:7026-35.

118. Gerwins P, Blank JL, Johnson GL. Cloning of a novel mitogen-activated protein kinase kinase kinase, MEKK4, that selectively regulates the c-Jun amino terminal kinase pathway. J Biol Chem 1997; 272:8288-95.

119. Fanger GR, Lassignal-Johnson N, Johnson GL. MEK kinase are regulated by EGF and selectively interact with Rac/Cdc42. EMBO J 1997; 16:4961-72.

120. Lamarche N, Tapon N, Stowers L, Burbelo PD, Aspenstrom P, Bridges T, Chant J, Hall A. Rac and Cdc42 induce actin polymerization and $\mathrm{G} 1$ cell cycle progression independently of p65PAK and the JNK/SAPK MAP kinase cascade. Cell 1996; 87:519-29. 121. Knaus UG, Morris S, Dong HJ, Chernoff J, Bokoch GM. Regulation of human leukocyte p21-activated kinases through G protein-- coupled receptors. Science 1995; 269:221-3.

122. Sells MA, Knaus UG, Bagrodia S, Ambrose DM, Bokoch GM, Chernoff J. Human p21-activated kinase (PAK1) regulates actin organization in mammalian cells. Current Biol 1997; 7:202-10.

123. Manser E, Huang HY, Loo TH, Chen XQ, Dong JM, Leung T, Lim L. Expression of constitutively active alpha-PAK reveals effects of the kinase on actin and focal complexes. Mol Cell Biol 1997; 17:1129-43.

124. Thompson CB. Apoptosis in the pathogenesis and treatment of disease. Science 1995; 267:1456-62.

125. Evan G. Cancer: a matter of life and cell death. Int J Cancer 1997; 71:709-11.

126. Martin SJ, Green DR, Cotter TG. Dicing with death: dissecting the components of the apoptosis machinery. Trends Biochem Sci 1994; 19:26-30.

127. Hale AJ, Smith CA, Sutherland LC, Stoneman VE, Longthorne VL, Culhane AC, Williams GT. Apoptosis: molecular regulation of cell death. Eur J Biochem 1996; 236:126.

128. Kauffmann-Zeh A, Rodriguez-Viciana P, Ulrich E, Gilbert C, Coffer P, Downward J, Evan G. Suppression of c-Myc-induced apoptosis by Ras signalling through $\mathrm{PI}(3) \mathrm{K}$ and PKB. Nature 1997; 385:544-8.

129. Khwaja A, Rodriguez-Viciana P, Wennstrom S, Warne PH, Downward J. Matrix adhesion and Ras transformation both activate a phosphoinositide $3-\mathrm{OH}$ kinase and protein kinase B/Akt cellular survival pathway. EMBO J 1997; 16:2783-93.

130. Gulbins E, Bissonnette R, Mahboubi A, Martin S, Nishioka W, Brunner T, Baier G, Baier-Bitterlich G, Byrd C, Lang F, et al. FAS-induced apoptosis is mediated via a ceramide-initiated RAS signaling pathway. Immunity 1995; 2:341-51. 
131. Henkemeyer M, Rossi DJ, Holmyard DP, Puri MC, Mbamalu G, Harpal K, Shih TS, Jacks $T$, Pawson T. Vascular system defects and neuronal apoptosis in mice lacking ras GTPase-activating protein. Nature 1995; 377:695-701.

132. Gomez J, Martinez C, Fernandez B, Garcia A, Reboilo A. Ras activation leads to cell proliferation or apoptotic cell death upon interleukin-2 stimulation or lymphokine deprivation, respectively [In Process Citation]. Eur J Immunol 1997; 27:1610-8.

133. Esteve P, del Peso L, Lacal JC. Induction of apoptosis by rho in NIH 3 T3 cells requires two complementary signals. Ceramides function as a progression factor for apoptosis. Oncogene 1995; 11:2657-65.

134. Fishbein JD, Dobrowsky RT, Bielawska A, Garrett S, Hannun YA. Ceramidemediated growth inhibition and CAPP are conserved in Saccharomyces cerevisiae. J Biol Chem 1993; 268:9255-61.

135. Jayadev S, Liu B, Bielawska AE, Lee JY, Nazaire F, Pushkareva M, Obeid LM, Hannun YA. Role for ceramide in cell cycle arrest. J Biol Chem 1995; 270:2047-52.

136. Obeid LM, Linardic CM, Karolak LA, Hannun YA. Programmed cell death induced by ceramide. Science 1993; 259:1769-71.

137. Obeid LM, Hannun YA. Ceramide: a stress signal and mediator of growth suppression and apoptosis. J Cell Biochem 1995; 58:191-8.

138. Lacal JC. Regulation of proliferation and apoptosis by Ras and Rho GTPases through specific phospholipid-dependent signaling. FEBS Lett 1997; 410:73-7.

139. Verheij M, Bose R, Lin XH, Yao B, Jarvis WD, Grant S, Birrer MJ, Szabo E, Zon $\mathrm{LI}$, Kyriakis JM, et al. Requirement for ceramide-initiated SAPK/JNK signalling in stressinduced apoptosis. Nature 1996; 380:75-9.

140. Gulbins E, Coggeshall KM, Brenner B, Schlottmann K, Linderkamp O, Lang F. Fas-induced apoptosis is mediated by activation of a Ras and Rac protein-regulated signaling pathway. J Biol Chem 1996; 271:26389-94.

141. Moorman JP, Bobak DA, Hahn CS. Inactivation of the small GTP binding protein Rho induces multinucleate cell formation and apoptosis in murine T lymphoma EL4. J Immunol 1996; 156:4146-53.

142. Brenner B, Koppenhoefer U, Weinstock C, Linderkamp O, Lang F, Gulbins E. Fasor Ceramide-induced Apoptosis Is Mediated by a Rac1-regulated Activation of Jun Nterminal Kinase/p38 Kinases and GADD153. J Biol Chem 1997; 272:22173-81.

143. Bruhat $A$, Jousse $C$, Wang $X Z$, Ron D, Ferrara M, Fafournoux $P$. Amino acid limitation induces expression of CHOP, a CCAAT/enhancer binding protein-related gene, at both transcriptional and post- transcriptional levels. J Biol Chem 1997; 272:17588-93.

144. Wang XZ, Lawson B, Brewer JW, Zinszner H, Sanjay A, Mi LJ, Boorstein R, Kreibich G, Hendershot LM, Ron D. Signals from the stressed endoplasmic reticulum induce C/EBP-homologous protein (CHOP/GADD153). Mol Cell Biol 1996; 16:4273-80.

145. Donovan FM, Pike CJ, Cotman CW, Cunningham DD. Thrombin induces apoptosis in cultured neurons and astrocytes via a pathway requiring tyrosine kinase and RhoA activities. J Neurosci 1997; 17:5316-26.

146. Lores P, Morin L, Luna R, Gacon G. Enhanced apoptosis in the thymus of transgenic mice expressing constitutively activated forms of human Rac2GTPase. Oncogene 1997; 15:601-5. 


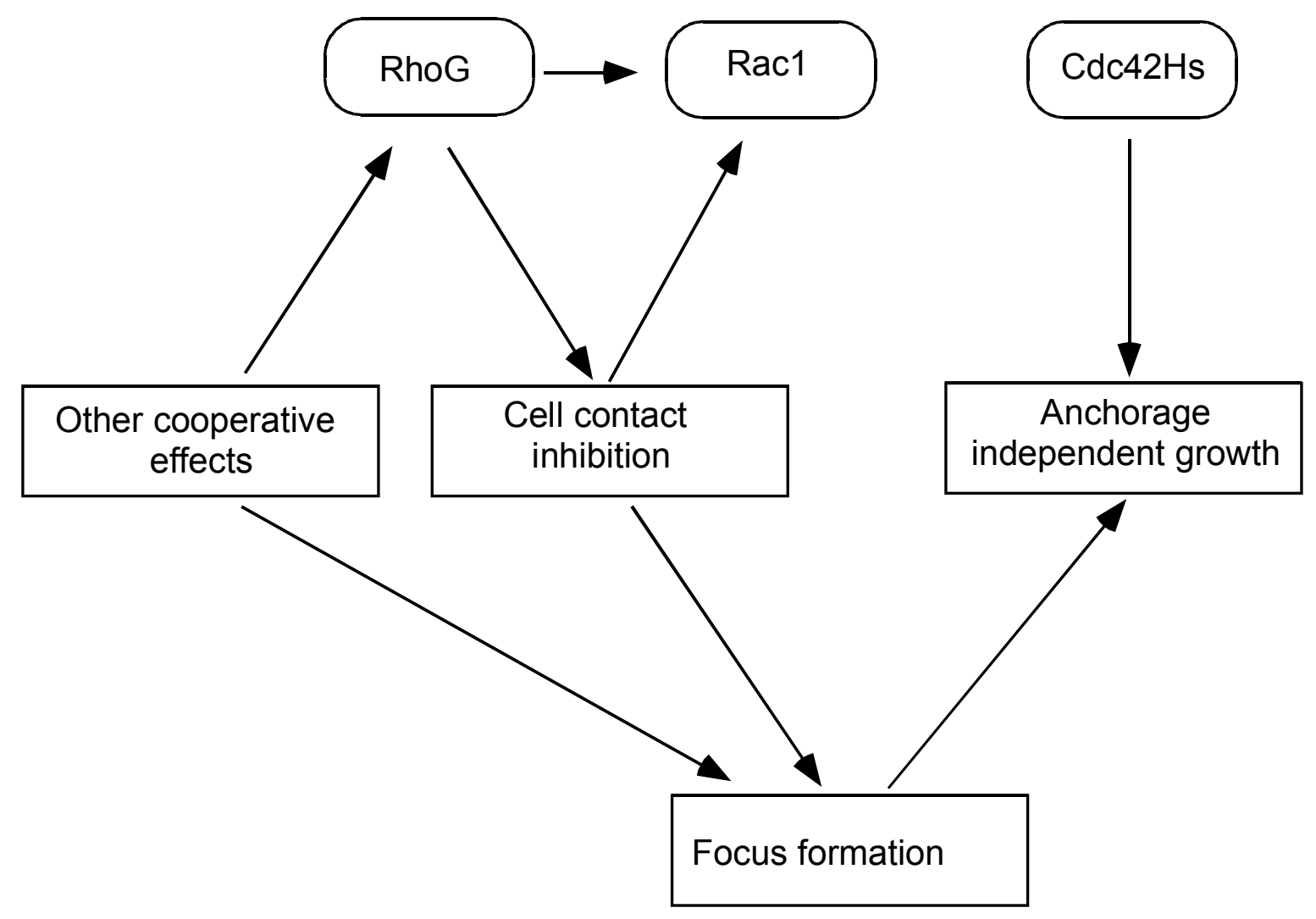

Figure1: Model for cooperativity of Rho GTPases in focus formation.

Cdc42Hs and RhoA promote anchorage-independent growth, while RhoG and Rac reduce cell contact inhibition. The simultaneous activation of both pathways leads to a high focus forming activity. RhoG is thought to act mainly upstream of Rac, although additional cooperative effects are suspected. 


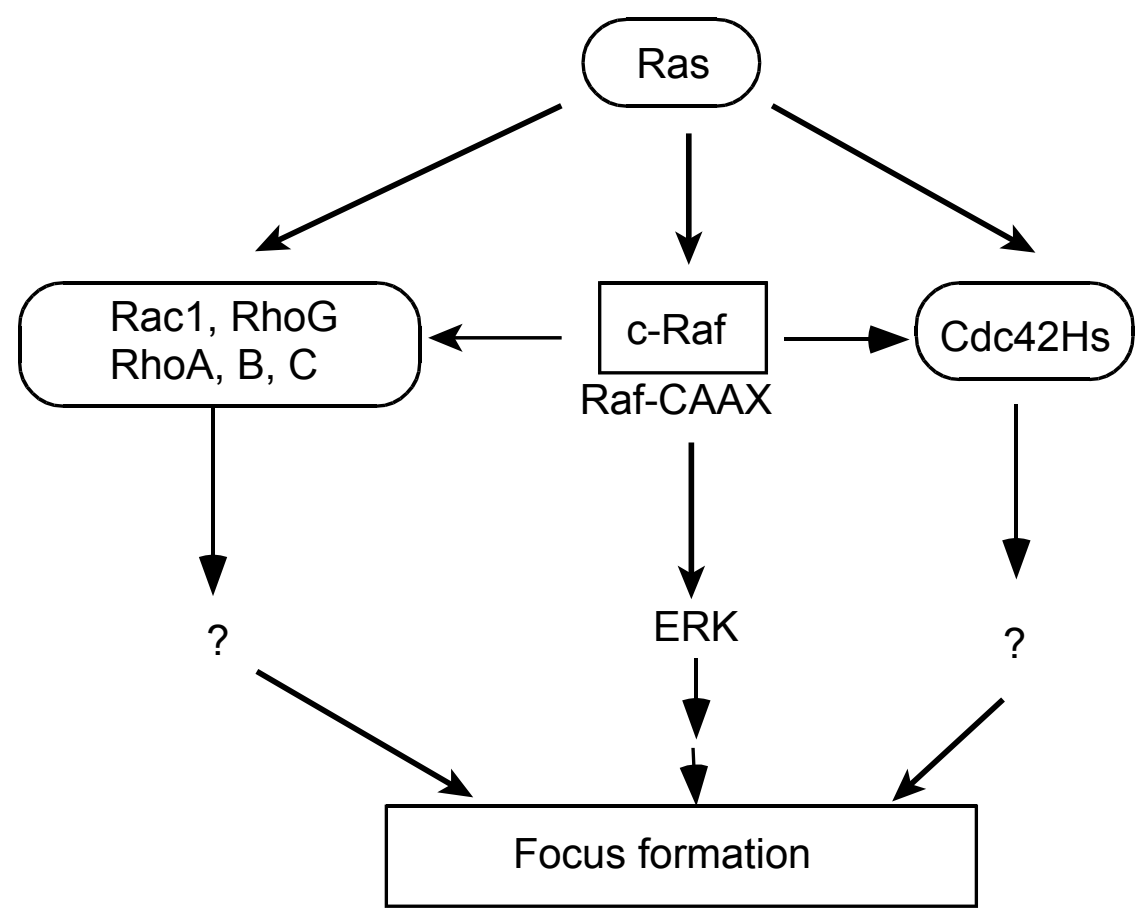

Figure2: Role of the Rho family in Ras- and Raf-mediated transformation. The activity of all Rho members is required for Ras transformation. Depending on the cell system used, RhoA and $\mathrm{Cdc} 42 \mathrm{Hs}$ activities are dispensable or required for Raf transformation (grey arrows). All activated Rho GTPases cooperate with Ras and Raf. The mechanisms by which constitutively activated Raf by-passes Rho proteins pathways are still unknown. 


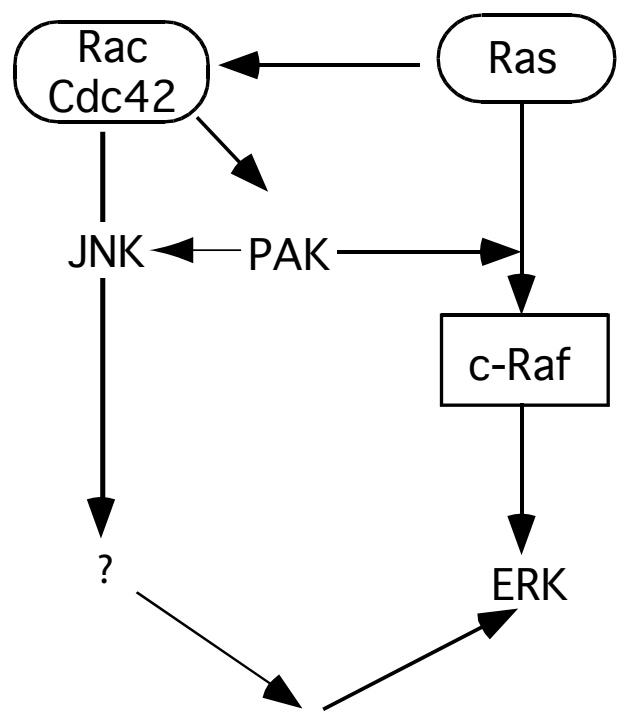

Focus formation

Figure3: Implication of pathways downstream of Rho proteins in focus formation. Selective activation of effectors was performed using specific Rac and Cdc42Hs variant proteins. Activation of PAK is required for Ras but not Raf transformation. JNK pathway is activated independently by PAK, Rac and Cdc42Hs, and is not involved in cooperation with Raf. Similarly, the formation of lamellipodia and filopodia elicited by Rac and $\mathrm{Cdc} 42 \mathrm{Hs}$ respectively is independent from the cooperation process. 


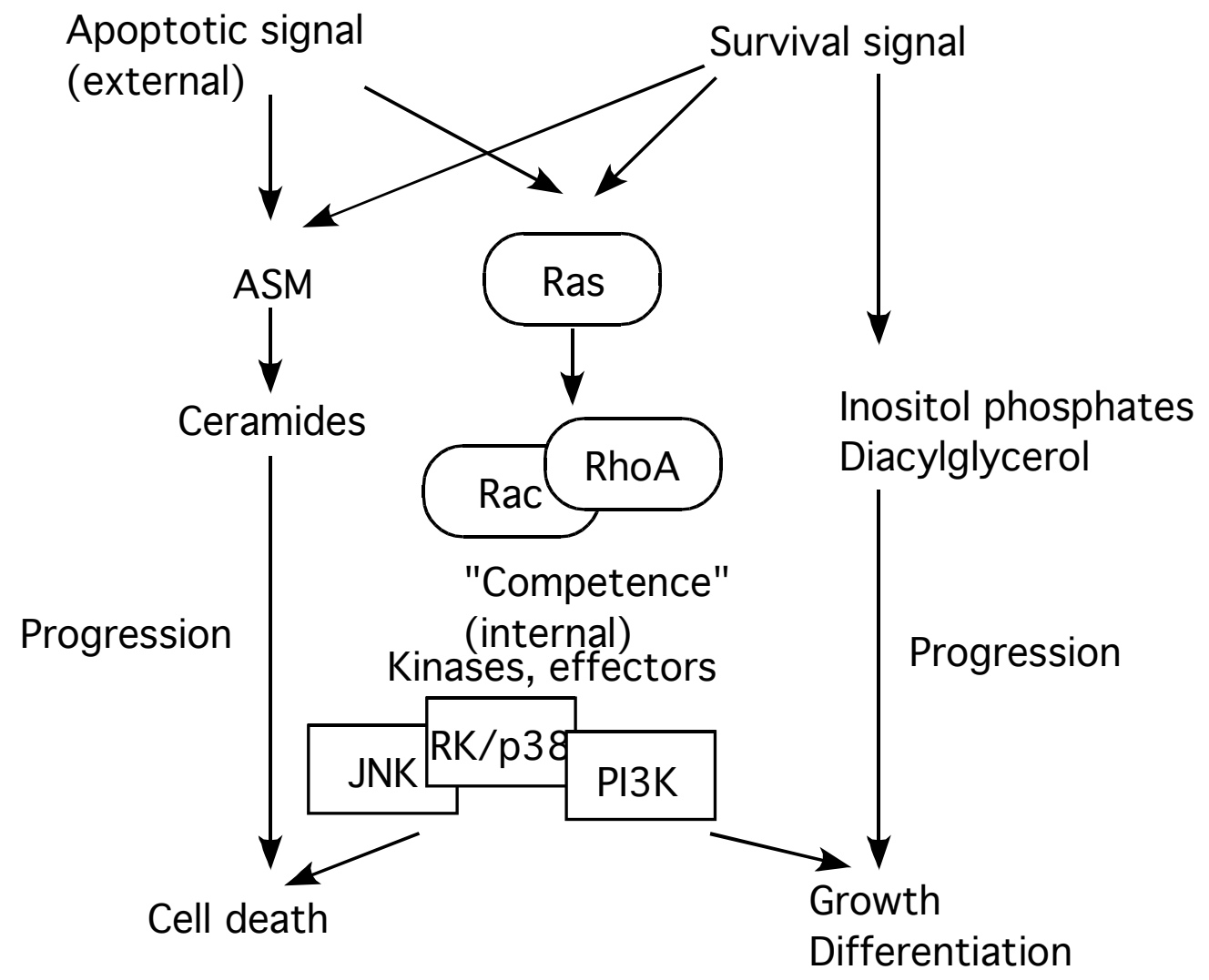

Figure 4: Role of Ras and Rho protein in the control of apoptosis. Cell fate is determined through a combination of external and internal signals. Apoptotic or survival signals use Ras/Rho pathways, which participate in the competence. Additional pathways such as ceramide production are required for the progression towards apoptosis. Conversely, survival signal inhibits ceramide production, and activates distinct pathways required for cell proliferation and transformation. 